The moths, which have been so numerous this summer, with the fore-wings dark in color and the hind wings a lighter shade, and with a wing expanse of about two inches, are those of the Army Cutworm. What this portends in the matter of next year's increase of these insects remains to be seen.

\title{
FORESTRY
}

A. Ward

The article on forestry by $C$. Stuart Francis, in the first issue of this year's BIJE JAY is to be highly commended. Mr. Francis refers to the grasshopper infestation as something that could possibly be prevented from reaching the proportions that have been so evident this summer.

If forestry were undertaken more seriously and extended to the prairies, means would be provided for encouraging many insect-cating birds to stay where they are not at present.

The matter has been discussed and presented to the Department of Natural Resources, Regina. The presentation to the Department was the suggestion that eighty acres of land be set aside in every municipality for the planting of trees. It was suggested that the trees should be planted twenty feet between rows, so that they could be easily worked with a tractor.

Travelling west last November, after a very dry period, parts. of the prairie district presented a most miserable sight. The grass, nibbled as bare as the road, had the appearance of a desert area. The proximity to the adjacent wooded Cypress Hills does not seem to influence the surrounding semi-arid district.

A forestry station in that area might be the means of inducing more moisture and attracting many species of birds which do not stay there at the present time.

\section{ANNUAL NUEETING}

Plan to attend this meeting, "to be held in the Museum auditorium, Rogine, Friday, October 27. See page 4. 
